\title{
TINJAUAN PERSPEKTIF INTELEGENSIA MUSLIM TERHADAP GENEALOGI KELAS MENENGAH MUSLIM DI INDONESIA
}

\author{
Wasisto Raharjo Jati \\ Pusat Penelitian Politik LIPI Jakarta, Indonesia \\ E-mail: wasisto.raharjo.jati@gmail.com
}

\begin{abstract}
This article aims to analyze genealogies of Muslim middle class in Indonesia. It can be traced from three primary sources such as bourgeoisies, pilgrimage trip (hajj) to Mecca and Medina, and education. These three sources have intertwined each other to build up Muslim middle class in social strata system that branch off in two model; bourguoises class and intellectual class. In this section, bourguoises tends to form trade alliance against Chinese domaniance and western traders who had been given privilieges from colonial regime. Meanwhile, intellectual class had focused to form ideal state for umat in Indonesia. Both classes are united altogether to form Islamic state as ultimate goals. High tension of political constellation in post colonial period had resulted in nationalist group as regulator class in Indonesia. Regarding political negotiation from nationalist, Indonesian Muslim middle class focused to establish Muslim society according to Medinan principles. Modern influence based on western style has affected Islamic values in grass roots level, and this resulted in the rise of modern Muslim society that embraced western style of life.
\end{abstract}

Keywords: Muslim Middle Class, Intellectual Class, Islam Politic, Islam Populer.

\section{Pendahuluan}

Membincangkan kelas menengah Muslim di Indonesia sendiri adalah bentuk dari transfomasi Islam politik menuju Islam modernis. $\mathrm{Hal}$ ini dikarenakan terjadinya pergeseran paradigma dalam mengaktualisasikan Islam dalam kehidupan bernegara dan berbangsa. Kebutuhan adanya membentuk "Negara Islam" sebagai rumah besar umat Muslim berganti dengan ide "masyarakat madani" sebagai bentuk adaptif terhadap modernitas dan sekularitas. Ada semangat 
negosiasi dan advokatif yang coba diterapkan oleh umat Islam dalam menegakkan eksistensinya melalui penerapan Islam secara substantif seraya berjalan harmonis dalam modernisasi zaman. Perubahan tersebut juga mengindikasikan bahwa pembangunan masyarakat seperti halnya umat Muslim pada saat zaman Madinah. Konteks tersebut sebenarnya juga ingin menunjukkan bahwa masyarakat Muslim bukanlah masyarakat yang sifatnya konservatif saja, melainkan masyarakat terbuka dan toleran terhadap zaman. Tolok ukurnya adalah semangat Piagam Madinah menjadi dasar terbentuknya masyarakat Muslim harmonis dan toleran. Spirit itulah yang hendak direvitalisasi dan direaktualisir oleh masyarakat Muslim kontemporer.

Pergeseran dalam paradigma kemudian menghasilkan perspektif mutakhir dalam membingkai kelas menengah baru di Indonesia, khususnya yang terjadi pada masa pasca Orde Baru. Kemunculan kelas menengah Muslim sendiri identik dengan adanya praktik supresif secara ekonomi-politik yang dilakukan oleh pemerintah baik semasa kolonialisme maupun republik. Kedua kondisi tersebut yang kemudian merumuskan mengenai kebangkitan secara politis tentang kelas menengah Muslim di Indonesia. Kebangkitan awal mengenai kelas menengah Muslim di Indonesia sendiri ditandai dengan adanya persaingan dagang yang kemudian berkembang dalam gerakan politik. Namun kemudian meredup pada saat republik yang senantiasa melakukan kebijakan subordinatif terhadap umat Muslim. Setelahnya kemudian mengalami transformasi kembali baik secara organisatoris dan ideologis yang memunculkan adanya kelas menengah yang akomodatif terhadap negara.

Tentunya dengan mencermati setiap rangkaian episode mengenai perubahan sifat dan karakter kelas menengah Muslim tersebut, kita bisa melihat adanya rangkaian benang intelektualisme yang disuguhkan untuk membingkai kelas menengah Muslim di Indonesia secara lebih luas dan komprehensif.

\section{Etos Kerja sebagai Dasar Pembentuk Kelas Menengah Muslim}

Basis fundamental dari kemunculan kelas menengah Muslim di Indonesia sendiri berasal dari kegiatan ekonomi perdagangan. Hal tersebut dapat diiindikasikan dari semangat Calvinisme yang kemudian juga meresap dalam pembentukan kelas menengah. Weber dalam karyanya Etika Protestan dan Spirit Kapitalisme menyebutkan adanya dua aspek penting agama menjadi dasar pembentuk etos kerja yakni 1) calling yakni "panggilan" bahwa manusia di dunia tersebut 
senantiasa bekerja dan bekerja demi menghindari sifat malas yang dibenci Tuhan. 2) asketisme dunia yang berarti hidup hemat sesuai dengan kebutuhan agar tidak boros menggunakan uang. Kedua hal tersebut menjadi dasar sehubungan dengan adanya doktrin predeterminisme yang berlaku dalam Islam bahwa berlaku hukum sebab-akibat atas perbuatan di dunia. ${ }^{1}$

Kedua premis itulah menjadi basis penting untuk menganalisis tumbuhnya kelas menengah Muslim di Indonesia. Secara normatif, pengenaan premis Calvinisme dalam mengerangkai kelas menengah Muslim di Indonesia bisa dikontekstualisir dengan munculnya gagasan semangat modernisme Islam. Pembaruan Islam pada dasarnya juga didasari atas kebutuhan untuk memperbaiki kualitas dan kondisi masyarakat Muslim yang pada umumnya termarjinalkan dalam sistem kolonialisme. Kondisi tersebut menjadikan masyarakat Muslim sendiri adalah korban dari sebuah sistem stratifikasi sosial yang tidak adil. Kondisi itulah yang menyebabkan semangat (geist) dalam merubah masyarakat tersebut muncul.

Namun demikian, perlu adanya eksaminasi lebih elaboratif mengenai pemaknaan geist untuk membedakan skala pengaruh Calvinisme dalam membentuk kultur masyarakat kelas menengah Muslim dengan kelas menengah Barat. Pembilahan tersebut menjadi urgen dan signifikan untuk melihat perbedaan pengaruh etos dalam menstimulus berkerjanya norma dan nilai agama secara praktikal. Adapun pembilahan tersebut dapat disarikan melalui tabulasi berikut ini.

Tabel 1:

Komparasi Makna "Geist"

dalam Kelas Menengah Barat dan Muslim

\begin{tabular}{|c|l|l|l|}
\hline No & Indikator & Kelas Menengah Barat & $\begin{array}{l}\text { Kelas Menengah Muslim } \\
\text { Indonesia }\end{array}$ \\
\hline 1. & $\begin{array}{l}\text { Orientasi } \\
\text { Kerja }\end{array}$ & $\begin{array}{l}\text { Mencari laba secara } \\
\text { akumulatif demi } \\
\text { kepenti-ngan pribadi }\end{array}$ & $\begin{array}{l}\text { Pengedepanan spirit Al- } \\
\text { Mấn sebagai bentuk } \\
\text { aksi filantropi sosial }\end{array}$ \\
\hline 2 & $\begin{array}{l}\text { Basis } \\
\text { ekonomi }\end{array}$ & $\begin{array}{l}\text { Industrialisasi berbasis } \\
\text { manufaktur }\end{array}$ & $\begin{array}{l}\text { Perdagangan, pertanian, } \\
\text { dan sektor usaha } \\
\text { ekstratif lainnya }\end{array}$ \\
\hline 3 & $\begin{array}{l}\text { Basis } \\
\text { Keanggotaan }\end{array}$ & $\begin{array}{l}\text { Borjuasi, kalangan } \\
\text { profe-sional, dan }\end{array}$ & $\begin{array}{l}\text { Kalangan } \\
\text { pedesaan, dan buruh }\end{array}$ \\
\hline
\end{tabular}

1 Max Weber, Etika Protestan dan Spirit Kapitalisme (Yogyakarta: Pustaka Pelajar, 2006), 117. 


\begin{tabular}{|c|l|l|l|}
\hline & & intelegensia. & \\
\hline 4 & $\begin{array}{l}\text { Relasi } \\
\text { dengan } \\
\text { Negara }\end{array}$ & $\begin{array}{l}\text { Independen dan berke- } \\
\text { mbang menjadi kelom- } \\
\text { pok penekan suppresed } \\
\text { group) }\end{array}$ & $\begin{array}{l}\text { Dependen dengan peng- } \\
\text { uasa, lebih mengarahkan } \\
\text { pada pelayanan sosial }\end{array}$ \\
\hline 5 & $\begin{array}{l}\text { Modal dan } \\
\text { Alat } \\
\text { Produksi }\end{array}$ & $\begin{array}{l}\text { Padat Modal } \\
\text { padat karya }\end{array}$ \\
\hline
\end{tabular}

Sumber: diolah dari berbagai sumber data.

\section{Genealogi Mula Kelas Menengah Muslim: Jaringan Perdagangan dan Intelektualisme}

Terdapat perbedaan cukup mencolok untuk melakukan komparasi antara pembangunan kelas menengah Barat dengan kelas menengah Muslim, di antaranya adalah kelas menengah Barat cenderung individualis dan kelas menengah Muslim cenderung menggali nilainilai filantropis, voluntarisme, dan kasih sayang terhadap sesama umat. ${ }^{2}$ Namun demikian, cara pandang Calvinisme untuk membingkai kemunculan kelas menengah Muslim sendiri juga masih dalam perdebatan. Kasus Muhammadiyah sendiri tidak selalu berlandaskan pada Calvinisme an sich saja, namun juga dimensi sebagai sebuah jam ‘yah itu juga dikuatkan dalam bentuk penguatan fungsi sosial keagaaman sesuai dengan prinsip al-mâûn. Kondisi itulah yang menjadikan kelas menengah Muslim di Indonesia sendiri serupa tapi tak sama dengan kemunculan kelas menengah Barat.

Selain halnya dimensi jam 'yyah sebagai suatu umat dan filantropis (al-mâûn). Hal lain yang perlu dianalisis mengenai dasar pembentukan kelas menengah Muslim adalah pembebasan. Makna pembebasan sendiri dalam kelas menengah Muslim merupakan implikasi dari waḥdanîah mulai beralih pada 'aqîdah taḥarruriyah yakni teologi yang mengarah pada pembebasan manusia dari segala bentuk ketertindasan. ${ }^{4}$ Namun lebih dari itu, peranan intelegensia Muslim yang terbangun melalui konektivitas menjadi penting untuk dianalisis.

Terdapat dua hal penting dalam membahas konektivitas intelegensia tersebut yakni 1) jaringan yakni berupa relasi

\footnotetext{
${ }^{2}$ Hilman Latief, Melayani Umat: Filantropi Islam dan Ideologi Kesejabteraan Kaum Modernis (Jakarta: Gramedia Pustaka Utama, 2010), 109.

3 Zuly Qodir, Mubammadiyah Studies: Reorientasi Gerakan dan Pemikiran Memasuki Abad Kedua (Yogyakarta: Kanisius, 2010), 50.

4 Wasisto R. Jati, "Agama dan Politik: Teologi Pembebasan sebagai Arena Profetisasi Agama”, W alisongo, Vol. 22, No. 1 (2014), 133-156.
} 
intelektualisme yang dibangun melalui relasi dakwah antara kalangan intelegensia Timur Tengah yang berpusat di Haramayn (Mekkah dan Madinah) dengan para ulama di Nusantara. 2) Transmisi yakni diseminasi berbagai macam gagasan intelektualisme Islam tersebar di berbagai tempat yang merupakan refleksi aktivitas intelektualisme yang terkait tersebut. ${ }^{5}$ Dari kedua proses tersebut terbentuk berbagai macam pusat intelektualisme di berbagai belahan Nusantara seperti halnya Aceh, Banjarmasin, Cirebon, Makassar, dan lain sebagainya pada abad 17-18. Pusat intelektualisme tersebut juga berkelindan dengan terbentuknya komunitas Islam yang merupakan manifestasi enclave dari menyebarnya gagasan intelektualisme.

Selain halnya Haramayn yang menjadi basis intelektualisme Islam, kawasan Hadramî juga turut mempengaruhi perkembangan intelektualisme Islam di Indonesia. Dari berbagai macam corak intelekualisme Islam tersebut muncullah dua pemahaman besar, yakni purifikasi Islam berbasis Pan-Islamisme dan juga konservatisme Islam dengan kembali pada ajaran, perilaku, tindakan Nabi Muhammad. Oleh karena itulah, dua karakter intelekualisme itulah yang turut mempengaruhi gerak dan karakter kelas menengah Muslim di Indonesia. Adanya gerak intelektualisme tersebut sebenarnya merupakan bentuk transformasi relasi dunia Islam di Nusantara dengan pihak-pihak luar. Sebelumnya jaringan yang terbentuk lebih pada korporasi politik misalnya saja Turki Ottoman dengan Aceh, Malaka dengan Mataram atau Demak. Periode kerjasama politik itu lebih dikaitkan adanya kesamaan mazhab agama dan perluasan jaringan perdagangan. Adapun jaringan dan transmisi tersebut kemudian diinstrumentasikan juga dalam bentuk kegiatan perdagangan.

Terdapat hal penting dalam memahami jejaring intelektualisme tersebut yakni adanya sanad dan silsilah sebagai dasar mula mata rantai intelektualisme antara Hadramî dengan Islam Nusantara. Selain itu pula terdapat pergeseran teologis pula yang terdapat dalam jejaring itu yakni munculnya neo-sufisme sebagai bentuk akulturasi dari tasawuf dan juga sharî́ah yang lebih menekankan pada pembangunan masyarakat Muslim daripada pembangunan kesalehan pribadi. Dari

\footnotetext{
${ }^{5}$ Moeflich Hasbullah, "Kompleksitas dan Jaringan Rumit Ulama Nusantara”, dalam www.academia.edu/ 9550136/Book_Review_Jaringan_Ulama_Azra. Diakses 1703-2015.
} 
situlah kemudian, peran kelas menengah Muslim sendiri mulai muncul sebagai inisiator masyarakat Muslim. ${ }^{6}$

Perdagangan menjadi basis penting dalam pembangunan politik kelas menengah Muslim di Indonesia, berimplikasi pada tumbuhnya semangat modernisasi masyarakat dan Islam. Pada umumnya, semangat tersebut diinisiasi oleh kalangan borjuasi elite yang menguasai perdagangan besar utamanya batik. Kemunculan tokohtokoh seperti halnya Ahmad Dahlan (Muhammadiyah), Haji Muhammad Yunus (Persis), maupun juga Samanhudi (Syarikat Islam) merupakan figur organisasi yang tumbuh dari basis kelas menengah urban. Perdagangan menjadi media kultural terhadap penyebaran gagasan intelektualisme baru dalam pembangunan masyarakat Muslim. Ragam intelektualisme Muslim seperti halnya Hasan al-Bannâ (Khilâfah Islamîyah), Jamâl al-Dîn al-Afghânî dan Muhammad 'Abduh (Modernisasi Islam), Ali Syariati (Islam Pembebasan) turut mempengaruhi gerak intelektualisme kelas menengah Muslim di Indonesia. Perdagangan pula yang kemudian menciptakan komunitaskomunitas kelas menengah Muslim.

Maka, perdagangan menjadi titik kunci dalam membangun kelas menengah Muslim di mana melalui kegiatan tersebut kemudian menstimulus adanya pertumbuhan pusat-pusat ekonomi di Jawa pada abad 19. Hal itulah yang kemudian menciptakan jejaring dengan pengusaha pribumi lokal sehingga proses Islamisasi sendiri berlangsung harmonis. Kajian Anthony Reid maupun juga Lombard melihat bahwa dimensi perdagangan global yang terjadi pada abad 19 sendiri tidak hanya membincangkan mengenai dimensi ekonomi, akan tetapi juga dimensi politik dan kultural.

Terdapat inisiasi ekspansi Haḍramî untuk mengembangkan jaringannya di Indonesia akibat adanya konflik politik yang terjadi di Semenanjung Arab. Perdagangan menjadi senjata dalam melakukan infiltrasi politik ke daerah baru. Pertemuan antara pedagang Arab dengan borjuasi lokal yang kemudian menciptakan permukimanpermukiman pedagang Muslim di pesisir Jawa yang kemudian menjadi awal tumbuhnya kelas menengah Muslim Indonesia yang didominasi kaum pedagang lintas pulau. Selanjutnya, pasca perdagangan menjadi basis awal terbentuknya kelas menengah Muslim.

6 Oman Fathurahman, "Jaringan Ulama: Pembaharuan dan Rekonsiliasi dalam Tradisi Intelektual Islam di Dunia Melayu-Indonesia”, Studia Islamika, Vol. 11, No. 2 (2004), 361-385. 
Fase selanjutnya setelah perdagangan adalah pendidikan. Dimasukkannya pendidikan sebagai basis penting terbentuknya kelas menengah Muslim di Indonesia sebenarnya merupakan bentuk kelanjutan dari diseminasi intelektualisme Islam tersebut. Pendidikan (tarbiyah) menjadi tahapan berikutnya dalam pembangunan kelas menengah Muslim yang termanifestasikan dengan adanya institusi surau, langgar, hingga pesantren. Hal itulah yang kemudian menjadikan organisasi kelas menengah urban seperti halnya Muhammadiyah maupun juga organisasi lainnya seperti halnya Nahdlatul Ulama membesar, dikarenakan melalui pendidikan itulah, pola relasi anggota masyarakat kemudian diikat sehingga terbentuklah modal sosial kelas.

Selain halnya perdagangan, perjalanan haji juga menjadi penting adanya indikasi tumbuhnya kelas menengah dari kegiatan perdagangan. Adanya intensitas haji itulah yang kemudian juga nantinya menciptakan ideologisasi politik Islam dalam karakter kelas menengah di Indonesia. Konteks haji tidaklah dimaknai sebagai bentuk perjalanan spiritual belaka, namun juga mengarahkan pada bentuk penguatan basis politik. Hal kentara yang bisa disimak dari haji adalah bertemunya berbagai macam aliran politik yang kemudian membidani komunitas kelas menengah berbasis afiliasi politik tersebut. Adanya penyematan gelar "haji", perubahan nama Islam setelah berhaji, dan juga penyematan nama daerah seperti halnya "alMinangkabawı̂", al-Jogjawî, dan lain sebagainya merupakan bagian dari penguatan haji secara politik.

Secara historis, perjalanan haji di Indonesia sendiri dilakukan oleh para elite borjuasi yang kemudian bertransformasi menjadi ulama atau menjadi hoofd penghulu memimpin komunitas masyarakat kecil. Oleh karena itulah, dalam kultur kelas menengah Muslim klasik sendiri di Indonesia terjadi pola patronase dalam pembentukan masyarakat kelas menengah sendiri. Tampilnya ulama sebenarnya adalah merupakan bentuk nabi sosial sekaligus juga penjaga moral bagi masyarakat. Makanya kemudian, sosok ulama menjadi figur yang terhomati dalam masyarakat. Selain halnya sebagai nabi sosial, peran ulama juga sebagai broker kultural untuk memastikan masyarakat sendiri tetap menjalankan sharî́ah agama. ${ }^{7}$ Kondisi kelas menengah Muslim yang masih mencari bentuk baik dalam membangun basis ekonomi

\footnotetext{
7 Zamakhsyari Dhofier, Tradisi Pesantren: Studi tentang Pandangan Hidup Kyai (Jakarta: LP3ES, 1994).
} 
maupun juga relasi sosial. Oleh karena itulah hadirnya ulama tampil sebagai figur pembangun umat tersebut.

Tabel 2:

Jalur Awal Perkembangan Genealogi Kelas Menengah Muslim

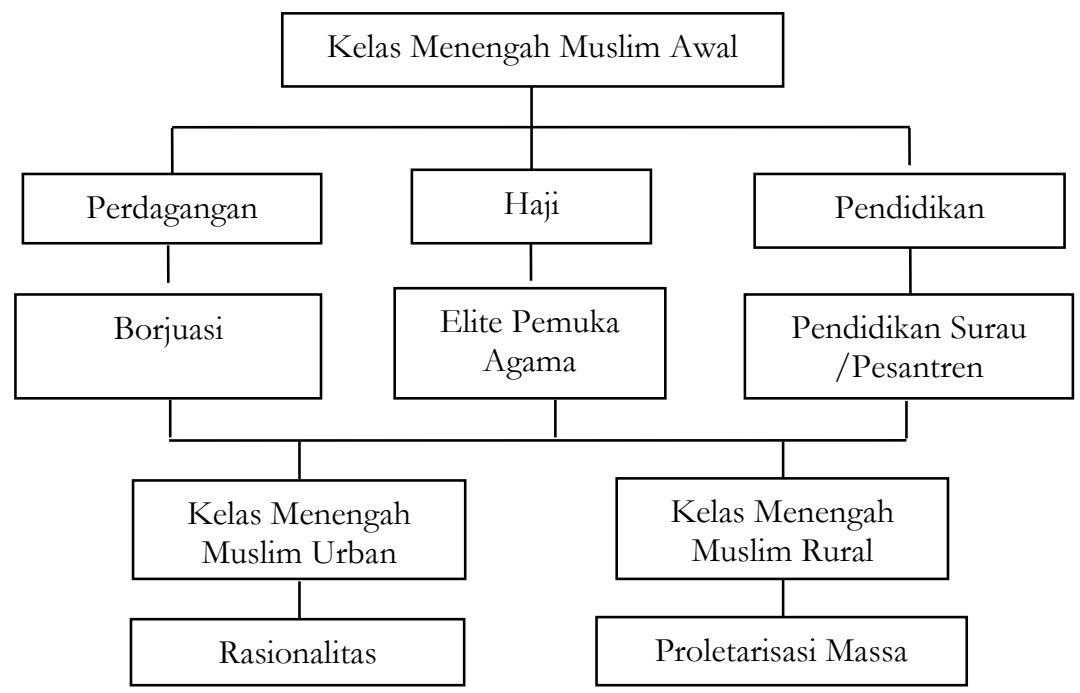

Sumber: diolah dari berbagai data

Adanya ketiga indikator yakni haji, perdagangan, dan pendidikan itulah sebenarnya yang menjadi dasar utama fondasi kelas menengah Muslim di Indonesia. Namun demikian, intensitas dengan konstelasi perkembangan Islam yang terjadi di Arab rupanya juga berpengaruh signifikan terhadap orientasi politik kelas menengah di Indonesia yang kemudian termanifestasikan ke dalam dua organisasi massa besar, Muhammadiyah dan Nahdlatul Ulama. Kedua organisasi besar tersebut mencerminkan adanya organisasi massa yang sebenarnya cermin adanya pembilahan karakter intelektualisme dan juga corak perdagangan yang menjadi basis kelas menengah di Indonesia. Pemilihan dua organisasi tersebut sebenarnya juga mencerminkan adanya perubahan sosial kemasyarakatan yang dialami masyarakat Indonesia.

Wetheim menyebutkan bahwa perubahan sosial masyarakat Indonesia yang semula berbasis komunal-kolektif menuju budaya 
organisatori merupakan bentuk langkah maju. ${ }^{8}$ Kebijakan Agrarische Wet 1860 dan juga pengenaan politik etis turut andil dalam membentuk kelas menengah Muslim di Indonesia. Agrarische Wet yang berujung pada liberalisasi ekonomi turut mengubah perekonomian Indonesia semula feodalisme menjadi industrialisasi sehingga membentuk spirit Calvinisme dalam membangun ekonomi. Adapun kebijakan politik etis telah melahirkan masyarakat pemikir yang peka terhadap isu sosial kemasyarakatan. Dua prakondisi mengenai perubahan sosial itulah yang juga merasuk dalam pembentukan kelas menengah Muslim di Indonesia yang semula konservatif-teologis menjadi lebih open minded. Pengaruh westernisasi dalam kelas menengah Muslim itulah yang kemudian menarik untuk dianalis dalam melihat munculnya organisasi kelas menengah seperti halnya Muhammadiyah dan Nahdlatul Ulama.

\section{Insiasi Tumbuh Kembangnya Kelas Menengah Muslim di Indonesia}

Ulasan mengenai konsep Weberian dalam mengerangkai kelas menengah Muslim utamanya dalam kasus Muhammadiyah dan NU di Indonesia banyak dianalisis oleh berbagai ilmuwan seperti halnya Lance Castle, Mitsuo Nakamura, Clifford Geertz, maupun juga Howard Dick. Pendekatan Weberian yang dominan dalam menganalisis kelas menengah Indonesia lebih mengarahkan analisis dalam dua kajian yakni 1) komparasi etos kerja kelas menengah Muslim dengan Barat dan 2) konstelasi negara dan kelas menengah Muslim. Catatan penting lain dalam menaruh konsep Calvin dalam kasus kelas menengah Muslim untuk membedakannya dengan pengalaman Barat adalah kemunculan kelas menengah Muslim ini sendiri masih parsial dan masih belum terorganisir sama sekali.

Pendirian kelas menengah Muslim di Indonesia sendiri pada dasarnya terbentuk dalam pola dependensi baik itu dilakukan oleh ulama melalui kegiatan syiar maupun elite borjuasi Muslim yang secara struktural dekat dengan penguasa. Kondisi tersebut sebenarnya mengindikasikan bahwa kekuasaan sendiri berkelindan dengan terbentuknya kelas menengah Muslim di Indonesia. Analisis awal mengenai kemunculan kelas menengah Muslim di Indonesia sebenarnya dapat dilacak dalam dua karya yakni Mitsuo Nakamura yang mengambil tempat lokusi penelitian di Kotagede dan Kauman

8 WF. Wetheim, Masyarakat Indonesia dalam Transisi: Kajian Perubaban Sosial (Yogyakarta: Tiara Wacana, 2010). 
sebagai basis Muhammadiyah. ${ }^{9}$ Karya klasik Clifford Geertz di Mojokuto (Pare, Kediri) merupakan basis Nahdlatul Ulama. ${ }^{10}$

Nakamura melihat kemunculan kelas menengah Muslim dalam kasus Muhammadiyah sendiri memiliki kemiripan dengan kasus kelas menengah Barat yakni bekerja keras, suka menabung, dan berinvestasi. Ketiga nilai tersebut yang nampak pola kerja para borjuasi kerajinan perak dan batik di kedua kawasan tersebut yang mengindikasikan adanya geist (semangat ekonomi) dalam kegiatan perekonomian. Munculnya geist sendiri tidak terlepas adanya pembaruan ajaran Islam di mana perdagangan menjadi kunci dalam melawan marjinalisasi Islam selama ini. Dipilihnya perdagangan juga tidak terlepas dari sosok Nabi Muhammad yang juga pedagang sehingga terdapat romantisasi ide bahwa perdagangan menjadi jalan menuju pembentukan masyarakat madani.

Kondisi tersebut merupakan bentuk empirik dari kontekstualisasi terhadap puritanisme Islam modern yang menggejala di Indonesia kala itu. Penekanan kelas menengah Muslim dalam kasus Muhammadiyah sendiri berasal dari dua jalur yakni emborjuasasi santri menjadi santri priyayi dan juga munculnya elite borjuasi yang memegang monopoli komoditas. Munculnya santri priyayi seperti halnya Ahmad Dahlan (Muhammadiyah) adalah kasus menarik tentang persinggungan santri dan priyayi sehingga membentuk kelas menengah Muslim di Yogyakarta. Meskipun ada nuansa elitisme dan menjadi pengasuhan penguasa, munculnya Muhammadiyah sebagai basis organisasi kelas menengah tersebut selain halnya sebagai upaya mereduksi sinkretisme dan tradisionalisme dalam ajaran Islam. Hal lain yang perlu diketahui adalah Muhammadiyah juga bagian jejaring borjuasi yang menggurita untuk melakukan proteksi usaha dagangnya terutama batik yang menjadi komoditi utama.

Pada umumnya basis kelas menengah Muhammadiyah ini adalah kalangan priyayi, birokrasi, pedagang, maupun juga intelektual berbasis urban yang kemudian mencerminkan adanya sikap rasionalitas dalam bermasyarakat. Berbagai macam elemen masyarakat kelas menengah yang dihimpun dalam Muhammmadiyah ini kemudian diikatkan dalam jalur dakwah. Instrumentasi dakwah

9 Mitsuo Nakamura, The Crescent Arises over the Banyan Tree: A Study of the Muhammadiyah Movement in a Central Javanese Town: 1910-2010 (Singapore: ISEAS Press, 2012).

${ }^{10}$ Clifford Geertz, Peddlers and Princes: Social Development and Economic Change in Two Indonesian Towns (Chicago: University Of Chicago Press, 1963). 
tersebut adalah tabligh menjadi syiar penting dalam membentuk basisbasis penting kelas menengah Muslim untuk mengikis adanya tarekat yang berbau mistik. Premis lain yang menjelaskan kelas menengah Muslim Muhammadiyah cepat berkembang adalah menawarkan adanya egalitarianisme dan progresivitas yang berorientasi pelayanan sosial kemasyarakatan, sehingga disukai oleh berbagai macam lapisan masyarakat.

Dalam konteks ini, kelas menengah ditempatkan sebagai umat sehingga memiliki karakter tersendiri sebagaimana masyarakat Madinah. Konteks gerakan kelas menengah Muhammadiyah sebagai umat ini yang menjadi basis penting kelas menengah secara organik. Munculnya Kauman itu sebenarnya merupakan manifestasi organik kelas mennegah tersebut yang membentuk komunitas tersendiri. Oleh karena itulah, munculnya Kauman baik yang terafiliasi dengan penguasa maupun pedagang di kawasan pesisir merupakan indikasi kelas menengah Muslim Muhammadiyah.

Sedangkan dalam kasus Geertz melalui kasus Mojokuto mengindikasikan bahwa kelas menengah sendiri dibangun atas transisi feodalisme menuju industrialisasi agraris berbasis rural area. Geertz membahasakan kelas menengah sebagai kelompok wong dagang yang teridentifikasi sebagai hadirnya santri borjuasi. Masuknya santri dalam ranah ekonomi juga tidak terlepas dari posisi pesantren sebagai pemilik tanah luas di pedesaan sehingga menjadi candradimuka bagi tumbuh kembangnya spirit kewirausahaan di desa. Kajian di Mojokuto juga menunjukkan bahwa peran kelas menengah dalam membangun perekonomian dengan mengenalkan spesialisasi kerja sehingga terjadi adanya pertukaran dagang. Pasar menjadi arena kontestasi kelas menengah santri dengan wong tjina dalam memperebutkan supremasinya. Kontestasi itulah yang kemudian menjadikan kelas menengah Muslim kemudian mengalami radikalisasi kolektif untuk merebut pangsa pasar tersebut. Namun adanya privilege wong tiina yang kemudian membuat posisi kelas menengah santri termarjinalkan.

Munculnya kelas menengah Muslim yang didominasi kalangan santri pesantren. Konteks pesantren sebagai entitas ekonomi sendiri tidak terlepas dari pengaruhnya sebagai penguasa tanah. Kondisi itulah yang kemudian memberikan stimulus bagi kalangan santri untuk terjun dalam perdagangan maupun kegiatan ekonomi lainnya. Pesantren menjadi ajang embourgoiment (borjuisasi) melalui 
perekonomian agraris tersebut sehingga kemudian menciptakan kelas pedagang baru dari proses stratifikasi kelas sosial dalam masyarakat Jawa yang terbagi atas berbagai kelas yakni kelas priyayi, kelas wong dagang, dan juga kelas wong cilik. ${ }^{11}$

Munculnya kelas wong dagang ini sebenarnya merupakan bentuk modernisasi perekonomian yang terjadi di Jawa dari pola agraris menuju industri perkebunan. Kondisi tersebut menciptakan adanya market centered society di berbagai pedesaan Jawa dengan berbasis aktivitas perilaku wong dagang tersebut. Pada dasarnya kelas wong dagang ini merupakan bentuk embrio kelas menengah di Jawa didominasi kalangan santri. Munculnya kelas menengah santri juga tidak terlepas dari persaingan dagang dengan kelas wong tjina. Kondisi itulah yang kemudian menjadikan stimulus kelas menengah Muslim hadir sebagai pedagang pribumi. Analisa lainnya mengenai munculnya borjuasi kelas menengah dalam masyarakat Indonesia dianalisis dalam bentuk perilaku sosial ketimbang persoalan laba dan rugi. ${ }^{12}$ Kondisi tersebut yang kemudian menciptakan adanya bentuk keterikatan antar-sesama anggota kelas menengah tersebut. Perilaku sosial kelas itu pulalah yang akan membedakan dengan kelas-kelas lainnya sehingga membentuk habitus kelas menengah Muslim. Perilaku sosial itu yang membedakan kelas menengah Muslim dengan pola kelas menengah lainnya.

Berbeda halnya dengan kelas menengah Muslim Muhammadiyah yang lebih rasional dan organik. Kelas menengah santri cenderung paternalistik dan emosional sehingga lebih cenderung melakukan aksi politik. Aksi yang digalang lebih mengarahkan pada bentuk proletarisasi massa. Hal inilah yang menyebabkan kelas menengah santri yang pada umumnya adalah kalangan pedesaan menjadi sangat sensitif terhadap isu politik. Adapun Nahdlatul Ulama sebagai payung organisasi kemudian mengambil posisi penting manakala masih tergabung dalam Masyumi, MIAI, dan organ korporatisme lainnya, sebelum akhirnya kemudian membentuk partai politik.

Dari kedua anasir dari Nakamura dan Geertz awal mengenai kelas menengah Muslim di Indoensia, terdapat dua karakteristik berbeda mengenai kelas menengah di Indonesia yakni bersifat rasional dan satunya lagi bersifat emosional. Namun demikian, ada hal terpenting

\footnotetext{
11 Ibid., 11.

12 Howard Dick, "The Rise of A Middle Class and Changing Concept of Equity in Indonesia”, Indonesia, Vol. 39, No. 1 (1985), 71-92.
} 
tentang perkembangan kelas menengah Muslim kemudian bertansformasi menjadi kelas intelegensia maupun juga massa proletar.

Muhammadiyah sendiri lebih mengarahkan diri pada bentuk kelas menengah Muslim puritan. Hal tersebut bisa dilihat dari fondasi umat Muhammadiyah sendiri yang berasal dari kalangan urban baik itu berasal pedagang, priyayi, maupun birokrasi. Sedangkan, Nahdlatul Ulama sendiri lebih berorientasi pada kultur kelas masyarakat menengah agraris yang didominasi oleh kelas petani dan buruh. Adanya perbedaan terhadap karakteristik kelas menengah Muslim yang teraktualisasikan dalam wujud kedua organisasi itulah berimplikasi pada orientasi politik Islam yang ditampilkan. Muhammadiyah merupakan personifikasi terhadap kalangan Muslim puritan yang menghendaki adanya modernisasi, sementara itu Nahdlatul Ulama adalah representasi Islam tradisional. Keduanya kemudian memberikan corak tersendiri terhadap gerak dan langkah intelektualisme kelas menengah Muslim di Indonesia untuk terjun dalam dunia politik melalui pembentukan berbagai macam organisasi politik. Maka, konteks membership yang dibentuk dalam organisasi politik tersebut juga mencerminkan adanya orientasi kelas menengah Muslim yang terfragmentasi. Corak tersebut terindikasi dari adanya sifat kelas menengah yang akomodatif dan revolusioner yang kemudian termanifestasikan dalam arah kejuangan organisasi.

Orientasi kelas menengah Muslim terbelah antara kebutuhan mendirikan sebuah negara "kesejahteraan" (dâr al-salâm) dengan pelayanan umat. Kedua konteks tersebut sebenarnya mengacu pada konsep negara Madinah sebagai landasan ideal bagi pembangunan masyarakat Muslim. Adanya percabangan dalam memaknai konteks Negara Madinah itulah yang kemudian perdebatan dalam memaknai Indonesia sebagai sebuah negara. Dalam kondisi tersebut yang kemudian menempatkan kelas menengah Muslim dalam posisi dilematis. Adanya negosiasi dan penerimaan sebuah entitas negara heterogen menjadi sebuah negara kesatuan. Meskipun dalam praktikya, terdapat kelompok Islam yang tidak sependapat dengan gagasan negara kesatuan, dan lebih condong mendirikan negara Islam melalui kekuatan politik.

Terjunnya gerakan kelas menengah Muslim dalam konstelasi politik Indonesia pada abad 20 didasari atas beberapa argumentasi. Pertama, adanya praktik kolonialisme yang telah memarjinalkan bangsa 
pribumi, utamanya umat Islam di mana kaum pribumi menjadi kelas ketiga setelah Eropa dan Timur Jauh. Kedua, adanya kebutuhan untuk mendirikan negara yang sesuai dengan aspirasi umat Islam Indonesia. Ketiga, semangat amr ma'rûf naby munkar dalam melawan kolonialisme yang dianggap sebagai "musuh" yang dianggap sebagai kaum kafir. Tumbuhnya berbagai macam organisasi politik yang dimotori oleh kelas menengah pada dasarnya merupakan benteng ekonomi terhadap diskriminasi ekonomi berupa praktik perdagangan maupun juga dalam politik. Membesarnya peran pedagang wong tiina dalam perekonomian juga tidak terlepas dari jaringan dagang yang dibangun berbasis klan. Belum lagi adanya kultur konfusianisme yang mendorong untuk selalu bekerja giat.

Transfrormasi kelas menengah Muslim di Indonesia dari semula massa menjadi umat dan kemudian menjadi kelompok kepentingan tentunya mengikuti arus periodeisasi politik. Periode penting tersebut ditandai dengan transformasi paradigma kelas menengah yang semula hanya Islam kulturalis menjadi Islam politik. Pembabakan kelas menengah Muslim menjadi kelas politik sendiri telah disinggung sebelumnya dengan berbagai macam organisasi politik. Premis penting dalam memahami kelas menengah sebagai kelas politik perlu mendapat analisa sebagai berikut ini.

\section{Transformasi Kelas Menengah Muslim dari Islam Kultural ke Islam Politik}

Perubahan mendasar mengenai kelas menengah Muslim yang semula hanya bergerak dalam ranah Islam kulturalis dan juga berfungsi new petty bourguoises. Seperti yang disinggung sebelumnya, adanya persaingan dagang dengan wong tjina menjadi argumentasi utama kelas menengah Muslim kemudian berubah haluan menjadi new social movement. Tumbuhnya gerakan di akar rumput juga bentuk konsolidasi para pedagang Muslim dalam menghadang dominasi pedagang wong tiina baik dari level produksi maupun juga mata rantai distribusinya.

Hadirnya Serikat Dagang Islam (SDI) pada tahun 1913 yang kemudian merubah dirinya menjadi Serikat Islam (SI) merupakan langkah inisiasi awal kelas menengah Muslim menjadi gerakan politik. Pola kapitalisme yang dibangun dalam perekonomian Indonesia pada abad 20 sendiri adalah kapitalisme yang tidak mendukung perkembangan usaha kelas menengah Muslim khususnya dalam bidang batik. Kondisi pelik itulah yang mendorong Serikat Dagang 
Islam kemudian tampil sebagai organisasi berpengaruh di awal abad ke-20 selain halnya Boedi Oetomo. Premis mendasar dari pembangunan Serikat Dagang Islam secara organisatoris adalah analisa kelas. Adapun analisa kelas yang dikembangkan oleh SDI lebih pada upaya marjinalisasi dan ketimpangan ekonomi yang dialami oleh saudagar Muslim. Pola kapitalisme yang dikembangkan sendiri hanya menguntungkan kalangan kelas Eropa dan Timur Jauh, dan tidak berpihak pada pengembangan kapitalisme pribumi. Bahkan H.O.S Cokroaminoto sendiri menyebut pola kapitalisme tersebut merupakan bentuk kapitalisme durhaka. ${ }^{13}$ Gagasan itulah yang kemudian merubah nama Serikat Dagang Islam menjadi Serikat Islam pada Kongres SDI pada tahun 1921.

Hal terpenting dari perubahan SDI menjadi SI adalah gagasan rumah besar umat Islam yang mempersatukan semua aliran politik kelas menengah Muslim baik yang sifatnya ortodoks, puritan, hingga konservatisme. Tujuan utama SI dalam analisa kelas yang mereka kembangkan adalah menumbangkan dominasi istimewa kelas wong tiina yang dianggap sebagai kelas previlieged dalam bidang ekonomi dan juga kelompok kelas bangsawan dan kolonial sebagai kelas previlieged dalam politik. Kelas menengah Muslim haruslah menjadi kelas utama dalam masyarakat Indonesia karena massanya yang besar. Adanya dua misi perjuangan kelas yang hendak dhimpun Serikat Islam baik sebagai gerakan pan-Islamisme dan juga gerakan proletariat massa justru menjadikan roda organisasi sendiri tidak berjalan secara simultan. Hal ini terkait dengan dua agenda tersebut membenturkan dua ideologisasi yang berbeda sehingga kedua tujuan malah beujung pada konflik.

Kuntowijoyo menjelaskan berbagai alasan kegagalan Serikat Islam justru mengalami kemunduruan dalam aksi perjuangan kelasnya. Pertama, kegagalan Serikat Islam dalam memperjuangkan progam ekonominya yang berbasis keadilan sosial justru kalah melawan dominasi kelas wong tiina. Hal ini dikarenakan kelas wong tjina ini merupakan established class yang mapan dalam penguasaan sumber daya ekonomi berikut rantai jarianganya. Hal itulah yang kemudian menghadang SI sendiri untuk mereduksi monopoli dagang yang dilakukan oleh wong tjina. Kedua, adanya faksionalisasi elemen kelas

13 Tarmizi Taher, Agama Kemanusiaan, Agama Masa Depan: Kontekstualisasi Kritis Doktrin Agama dalam Pembangunan dan Percaturan Global (Jakarta: Grafindo, 2004), 165. 
dalam tubuh SI sendiri di mana agenda perjuangan kelas menjadi kian revolusioner setelah masuknya paham komunisme dalam tubuh organisasi. Hal itulah yang kemudian memecah belah SI sendiri menjadi dua faksi yakni faksi SI "putih" yang dimotori Agus Salim, Samanhudi, dan lain sebagainya dan faksi SI "merah" yang dimotori oleh Semâ'ûn, Alimin, Darsono. Ketiga, Islam masih dianggap sebagai isu elitis yang kurang membumi. ${ }^{14}$ Para petinggi SI sendiri menggunakan Islam sebagai sarana mendapatkan kekuasaan. Hal itulah yang menjadikan Islam menjadi tereksluklusif. Padahal pemahaman demikian, sudah berusah didekonstruksi oleh Haji Misbach melalui ajaran "Islam Pembebasan" yang ingin menjadikan Islam lebih membumi. Namun hal itu sepertinya kurang berhasil, malah justru Misbach lebih cenderung ke arah proletarisasi massa.

Perpecahan dalam tubuh SI tersebut disinyalir lebih kepada agenda perjuangan kelas yang diusung organisasi SI sendiri mengalami orientasi yang tidak jelas. Agenda perjuangan kelas menengah Muslim sebagai umat dan juga agenda memperjuangkan kesejahteraan rakyat justru saling bertabrakan. Hal itulah yang kemudian menjadikan organisasi Serikat Islam kemudian banyak ditinggal oleh organ pendukungnya seperti halnya Muhammadiyah, Nahdlatul Ulama, PERTI, Persis, dan lain sebagainya. Kondisi itulah yang menjadikan SI kemudian bubar dengan sendirinya. Salah satu poin mendasar alasan SI tidak bisa mengartikulasikan kepentingan kelas menengah Muslim secara komprehensif adalah kurangnya memaksimalkan "Islam" secara strategis secara politik sebagai kelompok kepentingan. Kader-kader SI justru kalah bersaing dengan PNI maupun kekuatan politik lainnya yang lebih bisa menyuarakan kepentingan masyarakat secara meluas. Implikasinya kemudian kekuatan Islam politik yang diusung kelompok kelas menengah Muslim melalui SI ini kalah bersaing dengan kelompok nasionalis.

Kekalahan Islam politik yang diusung oleh kelas menengah Muslim di Indonesia lebih pada kurang pekaan terhadap isu-isu sosial di masyarakat. Posisi kelas menengah Muslim sendiri masih mendua yakni masih bersifat elitis karena berasal dari kalangan borjuasi dan intelektual, namun ingin memperjuangkan kepentingan kelompoknya dan rakyat secara meluas. Kemunduran Islam politik dalam tubuh SDI lebih dikarenakan kelompok kelas menengah Muslim ini hanya

14 Kuntowijoyo, Paradigma Islam: Interpretasi untuk Aksi (Bandung: Mizan Press, 2008), 250-253. 
menempatkan masalah ketimpangan dan marjinalisasi hanya dilihat secara internal, yakni lebih pada persoalan kalah modal maupun juga alat produksi. Seharunya pandangan terhadap lokus marjinalisasi tersebut perlu dilettakan dalam masalah ekternal yakni kolonialisme dan imperialisme. ${ }^{15}$

Hal itulah yang menjadi penyebab kelompok kelas menengah Muslim kalah dalam adu strategi politik dengan kelompok nasional. Studi Takashi Shiraishi melihat bahwa pada akhirnya kelompok SI merah yang mampu menggerakkan kekuatan kelas menengah menjadi kekuatan politik radikal. ${ }^{16}$ Kasus Surakarta menjadi titik simpul adanya radikalisasi kelas menengah yang dihimpun gerakan Islam progresif Haji Misbach untuk melawan adanya kekuatan aristokrasi dan juga kolonialisme. Meskipun kemudian gerakan tersebut diberangus, sosok Misbach sebagai ulama "merah" menjadi figur penting dalam melihat radikalisasi kelas menengah Muslim yang bergerak dalam level proletariat massa.

Selebihnya pasca Insiden Surakarta di tahun 1926 tersebut, Islam politik yang dihimpun oleh komponen kelas menengah Muslim menjadi mati suri. Terlebih ketika Muhammadiyah kemudian lebih berorientasi pada pelayaan sosial umat. Maka praktis Nahdlatul Ulama saja yang kemudian menjadi tulang punggung kelas menengah Muslim di Indonesia. Adapun konstelasi politik yang sedemikian berkembang kemudian menempatkan kelompok nasionalis dan agama menjadi dua kontestan utama politik. Anasir politik yang dikembangkan Feith dan Castle memperlihatkan adanya cleavages yang begitu kompetitif dalam melihat fragmentasi aliran ideologi masyarakat Indonesia yang disajikan dalam lima bentuk ideologi yakni Islamisme, komunisme, sosial demokrat, tradisionalisme, maupun juga nasionalisme. ${ }^{17}$ Pertautan kelas menengah Muslim menjadi kalangan priyayi santri maupun juga abangan santri menjadikan kekuatan politik kelas menengah Muslim menjadi turut terfragmentasi.

Nahdlatul Ulama menjadi satu-satunya poros kekuatan politik Islam dikarenakan adanya pembubaran Masyumi dan juga adanya radikalisasi Islam dengan munculnya DI/TII. Hal itulah yang

15 Syahrial Arifin, "Islam dan Pembebasan", dalam http://indoprogress.com /2012/08/Islam-dan-pembebasan/Diakses 28-03-2015.

16 Takashi Shiraishi, Zaman Bergerak: Radikalisme Rakyat di Jawa 1912 -1926 (Jakarta: Grafiti Press, 1997).

17 Herber Feith dan Castle (eds.), Pemikiran Politik Indonesia 1945-1965 Jakarta: LP3ES, 1988). 
menjadikan posisi kelas menengah Muslim dalam mengartikulasikan kepentingannya menjadi terhambat dikarenakan berbagai sebab, 1) stigmatisasi Islam yang lekat kaitannya dengan radikalisasi gerakan yang kemudian menuntut pemerintah mengawasi gerak-gerik umat Islam. 2) adanya persaingan dengan kelompok komunis dalam menjaring aspirasi massa yang kemudian berujung pada aksi konflik. 3) strereoryping yang dialamatkan dalam melihat kelas menengah Muslim sebagai kelas masyarakat "terbelakang" karena senantiasa berpakaian kolot terutama dalam melihat pakaian gamis maupun jilbab.

Berbagai macam stigmatisasi maupun juga stereotyping itulah yang kemudian merubah orientasi kelas menengah Muslim. Jikalau sebelumnya orientasi adalah spirit amar ma'rûf naby munkar dengan negara Islam seperti Madinah adalah tujuan utama, maka pasca tahun 1970-an sendiri orientasi kelas menengah Muslim di Indonesia sendiri lebih pada pembentukan masyarakat. Konteks tersebut kemudian acapkali disebut sebagai "Islam sipil". Munculnya transformasi tersebut lebih dikarenakan melihat kondisi pragmatis dan realistis tentang masyarakat Muslim di Indonesia yang terbelakng akibat kontestasi politik yang tidak seimbang. Maka, gagasan pembangunan masyarakat Muslim yang digagas kelas menengah Muslim adalah pilihan realis guna menerapakn nilai-nilai Madinah dalam suatu negara. Perubahan terhadap gagasan Islam politik menjadi Islam sipil sebenarnya juga tidak terlepas dari negosiasi dengan pemerintah Orde Baru. Manakala Pancasila kemudian ditetapkan sebagai asas tunggal dan juga adanya penerapan kebijakan massa mengambang (floating mass) untuk menerapkan adanya stabilisasi dalam masyarakat dengan depolitisasi. Implementasi penerapan Islam sipil merupakan jalan tengah agar stigmatisasi maupun juga stereotyping yang dilakukan oleh rezim pemerintah Orde Baru.

Selain halnya, negosiasi politik dengan pemerintah Orde Baru. Pandangan lain yang perlu untuk dijadikan pertimbangan adalah amalgamasi modernisasi dengan Islam yang kemudian menciptakan pandangan Islam modernis. Adanya pembangunanisme yang digalakkan oleh pemerintah di segala bidang turut mengilhami adanya perubahan dalam masyarakat Muslim. Sama halnya dengan genealogis munculnya kelas menengah Muslim di masa-masa kolonialisme yang didorong oleh kalangan borjuasi dan intelektualisme. Munculnya golongan menengah Muslim pada era tahun 1970-an sendiri lebih 
banyak didominasi kalangan kampus sekuler. Tentu hal ini menjadi menarik untuk mencemati, malah justru kalangan sekuler menjadi pemantik Islamisasi.

\section{Revivalisme Kelas Menengah dari Islam Politik ke Islam Sipil}

Dalam hal ini terdapat interseksi mengenai kebangkitan kelas menengah Muslim di Indonesia baik yang digerakkan aktivis kampus sekuler dan juga kalangan Universitas Islam Negeri. Selain itu pula, pola menarik juga terjadi dalam membaca pengaruh modernitas yang kemudian membentuk budaya Islam modern misalnya saja dalam gaya hidup, busana, dan lain sebagainya. Pelacakan mengenai genealogi kelas menengah Muslim selama Orde Baru dapat dianalisis dalam dua jalur yakni jalur intelektualisme dan juga jalur modernisasi. 1) jalur intelektualisme sendiri tidak terlepas dari pengaruh global ikhwân yang mendera di berbagai kampus sekuler maupun juga kebijakan Menteri Agama Tarmizi Taher yang melakukan modernisasi terhadap sistem pendidikan di berbagai Perguruan Tinggi Islam Negeri sehingga menciptakan adanya akulturasi dan westernisasi budaya pendidikan Barat ke dalam perguruan Islam. 2) munculnya budaya Islam yang terwakili dalam berbagai simbol misalnya saja; jilbab, lagu-lagu kasidah, ICMI, pendirian bank sharî̀ah atau media Islam, dan pengajian elite di tempat-tempat mewah. Dari dua sumber tersebut, pembahasan mengenai gagasan kelas menengah Muslim sendiri dapat dilacak sebagai bentuk penciptaan kesadaran kolektif kelas.

Kedua pandangan mengenai kelas menengah baru tersebut kemudian menciptakan adanya pengertian baru kelas menengah Muslim. Jikalau pada masa kolonialisme, kelas menengah Muslim sendiri dimaknai sebagai golongan santri-kyai dan juga pedagangpetani. Sementara dalam masa Orde Baru sendiri, pengertian kelas menengah santri kemudian mulai melebar dengan hadirnya kalangan birokrasi dan profesional masuk ke dalam golongan menengah Muslim. Pada dasarnya, pemahaman kelas menengah Muslim pada masa Orde Baru sendiri adalah golongan yang berorientasi pada doktrin pemahaman dan kebudayaan Islam, serta memiliki ruang dinamis antara proletarisasi massa dan borjuasi elite. Perluasaan keanggotaan mengenai kelas menengah baru tidak terlepas dari adanya priyayisasi santri yang dilakukan oleh Orde Baru melalui mesin birokrasi. Hal itulah yang menjadikan kelompok santri kemudian memasuki jalur birokrasi. 
Pembahasan genealogi kelas menengah pada Order Baru dan setelahnya bisa dilacak melalui gelombang Islamisasi yang melanda kampus-kampus negeri di Indonesia sehingga membentuk adanya kelompok-kelompok studi Islam seperti halnya Paramadina (Jakarta), Salman (Bandung), Shalahuddin (Yogyakarta), dan al-Akbar (Surabaya). Tumbuh kembangnya berbagai macam pusat studi Islam tersebut dimotori adanya semangat pembaruan Islam agar lebih bisa diterima publik agar lebih inklusif dan tidak ekstremis. Adapun generasi intelegensia kalangan kelas menengah Muslim di kampus sekuler ini juga sebagai bentuk kuratif terhadap gerakan Islam politik yang sebelumnya dilakukan oleh para elite kalangan menengah Muslim yang ternyata justru malah kian memojokkan kalangan umat Islam. ${ }^{18}$ Motor intelektualisme generasi kelas menengah yang dimotori oleh Nurcholish Madjid, Imadduddin Abdurrahim, maupun juga Dawam Rahardjo pada dekada 1970-80an adalah generasi kelas menengah yang coba mengampanyekan Islam sipil secara programatik melalui semangat intelektualisme agar Islam lebih membumi. Pengedepanan Islam secara programatik tersebut dapat dilakukan dalam bentuk penyebaran gagasan melalui media baik itu sifatnya akademis maupun populis.

Pertumbuhan media intelektual sebagai motor gerakan intelektualisme tersebut terindikasikan dengan tumbuhnya berbagai jurnal akademik yang dikelola oleh kalangan organisasi epistemik misalnya saja Jurnal Ulumul Qur'an (LSAF / Lembaga Studi Agama dan Filsafat), Jurnal Pemikiran Paramadina (Yayasan Paramadina), Jurnal Al-Hikmah (Yayasan Muthahhari), Prisma yang dikelola oleh LP3ES (Lembaga Penelitian, Pendidikan dan Penerangan Ekonomi dan Sosial), Pesantren dikelola (P3M (Perhimpunan Pengembangan Pesantren dan Masyarakat), Jurnal Prospektif yang dikelola PPSK (Pusat Pengkajian Strategi dan Kebijakan) ${ }^{19}$.

Terdapat berbagai macam postulat menarik dalam membingkai aspek masyarakat tamaddun. Pertama, konsep ini terkait dengan sejarah perkembangan Islam melalui narasi besar Nabi Muhammad membangun masyarakat Madinah. Kedua, masyarakat madani sendiri dibangun atas prinsip pluralisme, egalitarianisme, dan juga penegakan hukum yang jelas. Ketiga, pengertian tamaddun juga merujuk pada

\footnotetext{
${ }^{18}$ Kamaruzzaman Ahmad, "Melacak Akar Sosial-Politik Intelektual Islam Indonesia: Sebuah Survey Bibliografis", Kyoto Review of Southeast Asia, Vol. 8-9 (2007).

${ }^{19} \mathrm{Ibid}$
} 
sebuah fase transisi negara yang semula bersifat barbar menjadi lebih beradab. Adanya ketiga premis itulah yang menjadikan agenda membentuk kelas menengah Muslim menjadi sebuah masyarakat bertamaddun sendiri merupakan agenda urgen dan signifikan. Kondisi tersebut akan berdampak pada pendirian negara ideal sesuai dengan aspirasi kelas menengah Muslim. Gagasan masyarakat madani yang diusung oleh Madjid dan kawan-kawan melalui spirit masyarakat madani ini.

Nurcholish Madjid merupakan pionir dalam kebangkitan kelas menengah Muslim tersebut dengan menelurkan gagasan "masyarakat madani". Adapun pengertian "masyarakat madani" sendiri merujuk pada pengertian sistem sosial yang subur yang diasosiasikan dengan prinsip moral yang menjamin keseimbangan antara kebebasan perseorangan dengan kestabilan masyarakat. ${ }^{20} \mathrm{Hal}$ itulah yang kemudian mendorong Madjid kemudian mendirikan "Paramadina", yakni sebuah komunitas epistemik keilmuan yang kemudian dikembangkan menjadi sebuah universitas. Harapannya ialah dengan mendirikan sebuah universitas, maka gagasan mengenai masyarakat madani sendiri akan terdiseminasi. Dalam hal ini, gagasan masyarakat madani selaras dengan spirit Islam sipil yakni membentuk masyarakat Muslim yang tamaddun (beradab) yang terlepas dari segala macam unsur jâhilîyah. Pengertian lain mengenai masyarakat madani sendiri juga hadir dari Alatas yang menyatakan bahwa gagasan masyarakat madani sendiri adalah gagasan yang masih penuh kontroversi. ${ }^{21} \mathrm{Hal}$ tersebut dikemukakan oleh Alatas mengingat sisi pembangunan masyarakat Muslim yang hendak hendak dibangun oleh kelas menengah Muslim ini apakah jiplakan dari Barat, selaras dengan negara, atau merupakan inisiasi awal untuk mendirikan negara Islam. Alatas kemudian membandngkan spirit "Islam sipil" yang dibangun oleh Madjid dan elemen kelas menengah Muslim di kampus dengan "Islam Hadhari" yang digalakkan oleh Pemerintah Malaysia yang ternyata memiliki interseksi dalam membangun masyarakat beradab (civilized Islam), meski cara yang ditempuh Malaysia kemudian lebih berpihak pada Melayu yang dianggap sebagai "Islam" daripada etnis lainnya.

20 Wawan Mas'udi, "Masyarakat Madani: Visi Etis Islam tentang Civil Society", Jurnal Ilmu Sosial dan Ilmu Politik, Vol. 3, No. 2 (1999), 164-187.

${ }^{21}$ Syed Farid Alatas, "Ideology and Utopia in The Discourse on Civil Society" dalam Johan Saravanamuttu, Islam and Politic in Southeast Asia (New York: Routledge, 2010), 173-176. 
Kontestasi intelektualisme sesama generasi kelas menengah Muslim dalam mengerangkai kelas menengah Muslim tersebut kemudian direkam oleh Ahmad Baso Civil Society versus Masyarakat Madani. ${ }^{22}$ Baso sendiri melihat berbagai perdebatan akademik seputar gagasan "masyarakat madani ini. Adapun perdebatan akademik ini merupakan lanjutan dari berbagai aliran intelektual yang terangkum dalam berbagai macam publikasi jurnal ilmiah tersebut dan juga dari ICMI sendiri.

Perdebatan mengenai gagasan masyarakat madani itu pada akhirnya tidak produktif dan malah justru berujung pada eksklusivitas identitas kelompok kelas menengah Muslim itu sendiri berdasarkan pada afiliasi dan afinitasnya. 1) pemahaman mengenai kelas menengah Muslim dari kelompok ICMI yang digagas oleh Bachtiar Effendy yang melihat bahwa masyarakat madani sendiri mewakili semangat Madinah sesuai dengan ajaran Nabi Muhammad. 2) pandangan A.S Hikam yang melihat bahwa gagasan masyarakat madani sendiri merupakan imitasi dari spirit masyarakat sipil Tocquevilian yang melandaskan diri kepada pembangunan modal sosial. ${ }^{23}$ 3) pandangan bahwa masyarakat madani merupakan bentuk jam ŷyah sebagai persiapan pendirian negara Islam di Indonesia. Ketiga pandangan tersbeut sebenarnya juga mencerminkan adanya liberalisasi dalam pemikiran Islam terutama saat modernisasi pendidikan juga menggejala di kalangan pesantren. Implikasinya kemudian adanya berbagai macam pemikiran progresif di kalangan intelegensia Muslim.

Adanya saling perdebatan dalam merumuskan pandangan mengenai gagasan "masyarakat madani" juga tidak terlepas dari adanya ICMI. Pendirian ICMI yang dilakukan pemerintah Orde Baru sendiri juga mengandung berbagai multitafsir, yakni apakah ICMI dianggap sebagai bentuk kemenangan kelas menengah Muslim dalam arena percaturan negara atau justru merupakan sarana penundukan terhadap gerakan politik kelas menengah Muslim. Hefner dalam tulisannya berjudul Islam, State, and Civil Society: ICMI and the Struggle for the Indonesian Middle Class melihat pendirian ICMI juga tidak terlepas dari dua arus besar yakni 1) Islamisasi "tidak langsung" dalam pemerintahan Orde Baru yang ditunjukkan dengan munculnya

\footnotetext{
22 Ahmad Baso, Civil Society versus Masyarakat Madani: Arkeologi Pemikiran Civil Society dalam Islam Indonesia (Jakarta: Pustaka Hidayah, 1999).

23 Philip Kitley, "Civil Society and The Media In Indonesia" dalam Azyumardi Azra, Islam Beyond Conflict (Hampshire: Ashgate, 2008), 218.
} 
berbagai produk kebijakan seperti halnya UU Pernikahan, dibentuknya BAZIS, pendirian Bank Muamalat, maupun juga pendirian Harian Republika. 2) Islam dianggap sebagai mitra strategis dalam menyeimbangkan stabilisasi kekuasaan ${ }^{24}$.

Dua arus itulah yang menjadikan ICMI kemudian menjadi besar secara organisasi maupun jaringannya karena disokong oleh militer dan birokrat. Munculnya ICMI secara tidak langsung juga menimbulkan friksi baik sesama generasi intelegensia kelas menengah Muslim maupun juga kalangan "abangan". Bagi kalangan "abangan" melihat muncul ICMI sebagai ancaman politik mengingat pemerintahan Orde Baru sendiri sangat kental dengan nuansa sinkretisme Jawa. Hal itu yang menjadikan ICMI akan mereduksi pengaruh "abangan" tersebut. Sementara bagi kalangan internal pemikir kelas menengah macam Sri Bintang Pamungkas dan Abdurrahman Wahid melihat bahwa ICMI sendiri adalah kooptasi rezim terhadap gerakan politik kelas menengah Muslim di Indonesia. Kondisi tersebut yang keudian mendorong Gus Dur melalui Forum Demokrasi kemudian menggelorakan spirit Muslim Demokrat sebagai antiklimaks dari Islam Sipil yang digagas oleh Nurcholish Madjid. Menurut Gus Dur, pembangunan kelas menengah Muslim sendiri tidaklah perlu selaras dengan spirit Madinah, namun akan lebih baik selaras dengan prinsip demokratisasi. Hal itu lebih baik untuk meneguhkan posisi kelas menengah Muslim sendiri sebagai bagian proses demokrasi negara. Oleh karena itulah gagasan Muslim demokrat sendiri merupakan jalan tengah bagi kelas menengah Muslim untuk menanggalkan eksklusivitasnya dan lebih inklusif. Komparasi pemahaman antara Islam Sipil dengan Muslim Demokrat dapat disajikan dalam tabulasi berikut ini.

Tabel 3:

Komparasi Pandangan "Islam Sipil" dan "Muslim Demokrat"

\begin{tabular}{|c|c|c|c|}
\hline No & Parameter & Islam Sipil & Muslim Demokrat \\
\hline 1 & $\begin{array}{l}\text { Pembentukan } \\
\text { Masyarakat }\end{array}$ & $\begin{array}{l}\text { Masyarakat yang } \\
\text { memegang } \\
\text { prinsip Madinah sebagai } \\
\text { nilai. }\end{array}$ & $\begin{array}{lr}\text { Masyarakat dibentuk } \\
\text { selaras dengan } \\
\text { prinsip demokratisasi. }\end{array}$ \\
\hline 2 & Relasi Negara & $\begin{array}{lr}\text { Masyarakat } & \text { islami } \\
\text { merupakan jalan awal } \\
\text { terbentuknya negara }\end{array}$ & 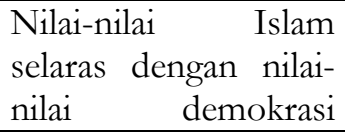 \\
\hline
\end{tabular}

${ }^{24}$ Robert Hefner, "Islam, State, and Civil Society: ICMI and the Struggle for the Indonesian Middle Class”, Indonesia, Vol. 56, No. 3 (1993), 1-35. 


\begin{tabular}{|c|l|l|l|}
\hline & & islami & negara \\
\hline 3 & Sifat & Eksklusif & Inklusif \\
\hline 4 & $\begin{array}{l}\text { Penegdepanan } \\
\text { Isu }\end{array}$ & Isu Moralitas & Isu-Isu Sosial Politik \\
\hline
\end{tabular}

Sumber: Diolah dari berbagai sumber

\section{Islam Populer sebagai Modernisasi Kelas Menengah Muslim}

Dampak modernisasi terhadap kelas menengah Muslim juga terasa dalam kehidupan sehari-hari. Seperti yang sudah disebutkan diatas yakni, jilbab, musik kasidah, pengajian elite, maupun juga tumbuhnya media menjadi indikator utama. Sebenarnya keempat indikator tersebut merupakan bentuk efek eksternal dari tumbuhnya kelas intelegensia Muslim itu sendiri. Terdapat dua pendapat untuk mengerangkai adanya bentuk modernisasi gaya hidup kelas menengah Muslim yakni 1) modal budaya (cultural capital) dan 2) praktik identitas kelas (class identity practice). Kedua hal tersebut menurut Heryanto melihatnya sebagai bentuk hubungan mutualisme antara Islam dengan budaya populer sehingga menciptakan adanya istilah "Islam Populer". Adapun istilah tersebut untuk mendeskripsikan adanya kebangkitan Islam dalam gaya hidup, nilai, dan norma untuk bisa diterapkan dalam kehidupan sehari-hari. Heryanto kemudian menganalisisnya dalam kaca mata hiburan dan gaya hidup di mana Islam populer mencoba untuk menunjukkan eksistensinya di tengah kuatnya pengaruh westernisasi maupun juga sinkretisme yang masih ada. ${ }^{25}$ Prakondisi itulah yang menyebabkan adanya penguatan membership bagi kelompok kelas menengah Muslim untuk menjaga dan menunjukkan eksistensinya. Pengertian modal budaya sebagai bentuk ikatan solidaritas bagi kelompok kelas menengah Muslim. Pengenaan jilbab yang kemudian tergeneralisir di lingkungan birokrasi, sekolah, maupun instansi sekuler menunjukkan adanya keberhasilan Islam populer dalam menyebarluaskan pengaruhnya. Begitu pun juga dengan musik kasidah dan juga saluran dakwah yang kini kian digemari oleh kalangan kelas menengah urban.

Howell menyebutnya sebagai bentuk televangelisme untuk melihat adanya infiltrasi pengaruh Islam populer dalam ranah media dan

25 Ariel Heryanto, Upgraded Piety and Pleasure: The New Middle Class and Islam in Indonesian Popular Culture in Andrew Weintraub, Islam and Popular Culture in Indonesia and Malaysia (New York: Routledge, 2008). 
dakwah. ${ }^{26}$ Kasus tersebut merujuk pada muncul dai selebritis seperti halnya Abdullah Gymnastiar (AA Gym), Jeffry Al Buchori (Uje), Arifin Ilham, maupun juga Maulana. Munculnya para dai ini juga bersinergis dengan kebutuhan kelas menengah urban untuk mencari dan menjaga nilai kesalehan sosial dalam kehidupan tanpa harus menanggalkan karakter modernitas. Pencarian terhadap nilai kesalehan sosial dalam kultur masyarakat kelas menengah urban yang sedemikian hedonistik dan liberal sangatlah menarik dikaji.

Munculnya kelas menengah Muslim di tengah masyarakat urban tentu merupakan anomali terhadap stigmatisasi yang dilekatkan Islam selama ini cenderung konservatif. Adanya komodifikasi nilai, norma, dan perilaku Muslim berinteraksi dengan budaya Barat seperti yang ada dalam contoh Islam populer ini. Hal itulah yang kemudian berkorelasi dengan tumbuhnya kelompok pengajian yang tersebar di berbagai sudut kota maupun desa. Dari situlah kemudian bisa dilacak mengenai adanya diseminasi sufisme dalam dakwah Islam di Indonesia yang lebih berfokus pada penerjemahan teks-teks al-Qur'ân dan Hadîth. Jika bisa diringkas secara lebih lanjut genealogi kelas menengah Muslim pasca Orde Baru sendiri dapat dilihat dalam bagan berikut ini.

Tabel 4:

Genealogi Kelas Menengah Muslim Pasca-Orde Baru

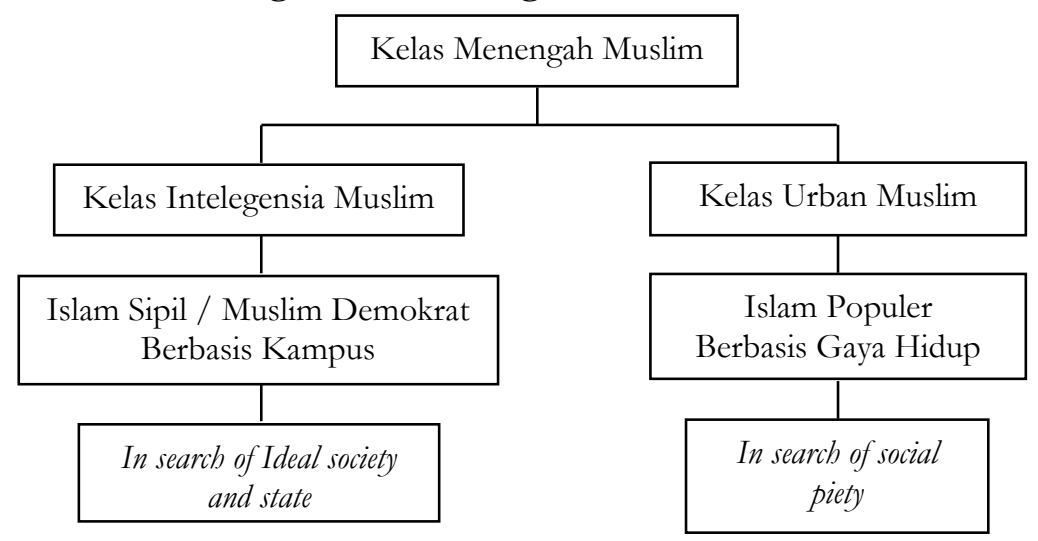

Dari tabulasi di atas, setidaknya terdapat dua orientasi yang berkembang dalam pemahaman genealogi kelas menengah

${ }^{26}$ Julia Howell, "Modulations of Active Piety: Professors and Televangelists as Promoters of Indonsian Muslim Sufism", dalam Greg Fealy, Expressing Islam: Religious Life and Politics in Indonesia (Singapore: Routledge, 2008), 42. 
kontemporer saat ini. Kelas intelegensia lebih sibuk pada urusan makro tentang perumusan relasi negara dengan umat maupun diseminasi hasil intelektualisme. Sementara itu, kelas menengah urban lebih sibuk pada pencarian dan pembentukan nilai kesalehan sosial baik sebagai individu maupun kelompok. Munculnya dua cara pandang yang dialami kelas menengah kontemporer lebih terletak pada bentuk penerimaan nilai-nilai Islam. Ada dua model penerimaan nilai-nilai Islam dalam membincangkan kelas menengah Muslim hari ini yakni emotional atau functional values dan juga spiritual values. Yang pertama, membahas mengenai emotional atau functional values dalam kultur kelas menengah Muslim lebih identik pada penerimaan nilai,norma, dan perilaku Islam yang belum sepenuhnya kâffah. Artinya, perilaku kelas menengah sedemikian lebih mengikuti arus mainstream masa kini ketika budaya Islam populer mulai bisa diterima bersamaan dengan budaya Barat. Hal itulah yang menjadi titik krusial dalam memahami kelas menengah Muslim yakni apakah menjadi Muslim adalah pilihan pribadi atau merupakan bagian dari perilaku kolektif kelas. Pada dasarnya dengan menjadikan Islam populer menjadi ikon yang diterjemahkan dalam berbagai produk budaya mulai dari fashion, kasidah, keuangan sharî́ah, dan lain sebagainya itu mengidentikkan perilaku kelas menengah sendiri menjadi Muslim secara artifisial. Model kelas menenegah sedemikian lebih melihat penerimaan nilai-nilai Islam secara fungsional saja, selebihnya penerapan rukun Islam dalam kehidupan sehari-hari masih dipertanyakan.

Hal tersebut cukup berbeda dengan penerimaan kelas menengah Muslim yang melihat dan menerima nilai-nilai Islam sebagai bentuk kesadaran spiritual. Kondisi spiritual values yang dialami oleh kelas menengah Muslim sendiri merupakan bentuk konfirmisitas sebagai umat Muslim untuk menjalankan perintah dan menjauhi laranganNya. Adapun konteks spiritual sendiri tidaklah identik pola dakwah Islam yang konservatif, namun disesuaikan dengan nilai-nilai modernitas yang dianut oleh kelas menengah Muslim masa kini. Penyebaran sufisme yang berimplikasi pada terbentuknya pengajianpengajian elite itu merupakan salah satu contoh kasus menarik. Di berbagai kota besar di Indonesia khususnya Jawa, terdapat revitalisasi jaringan dakwah Hậ̣ramî melalui model ḥabîh, ḥabâib, shaykh, dan lain sebagainya. Penguatan jaringan Hạdramî itu juga merupakan bentuk penguatan jaringan dakwah yang putus selama Orde Baru berkuasa. 
Maka selepas Orde Baru runtuh, komoditisasi isu-isu sosial kultural masyarakat seperti halnya mirasantika, seks bebas, dan lain sebagainya sendiri ternyata menjadi isu hidup yang kemudian mampu menjaring masyarakat kelas menengah Muslim untuk kembali pada jalan spiritual. Jaringan habâib yang menggejala di berbagai kota besar Indonesia juga menegaskan adanya kebutuhan spiritual masyarakat cenderung semakin meningkat. Dalam suatu sesi pengajian, bisa dipastikan yang hadir adalah kalangan menengah baik yang berpendapatan besar hingga kecil. Kebutuhan akan spiritualisme itu juga pada akhirnya juga berdampak melajunya roda ekonomi seperti halnya umroh dan haji, maupun juga biro ziarah lainnya.

\section{Penutup}

Perbincangan mengenai genealogis kelas menengah Muslim dalam konteks Indonesia mengalami banyak transformasi nilai maupun bentuk. Mulai dari kelas borjuasi, intelektualisme, lantas kemudian menjadi gaya hidup keseharian. Di antara berbagai macam rupa tersebut, Islam kemudian tidak lagi diterjemahkan dalam kontek kanonik, namun menjadi identitas kolektif yang mengikat setiap elemen anggota kelas tersebut. ${ }^{27}$ Pengedepanan isu awal seperti amar ma'rûf naby munkar kemudian berkembang menjadi arena dakwah inklusif yang mampu menjaring jumlah anggota kelas menengah tersebut.

Ada dua temuan menarik dalam mengelaborasi mengenai genealogi kelas menengah Muslim ini yakni 1) modal kultural dan 2) praktik kelas. Islam sebagai modal kultural sendiri kemudian dimaknai sebagai bentuk komoditisasi nilai, norma, maupun perilaku Islam menjadi bagian membentuk modal sosial dalam masyarakat. Kontek kesalehan sosial menjadi kunci utama dalam membangun kelas menengah Muslim tersebut agar disesuaikan dengan nilai-nilai Madinah ataupun juga demokratisasi negara. Adapun Islam sebagai praktik kelas sendiri dimaknai sebagai upaya menjaga umat Muslim agar menjadi kesatuan utuh. Hal ini memang bisa dianggap sebagai eksklusivitas, namun bisa juga dimaknai bentuk konservasi.

Pada akhirnya perbincangan mengenai genealogi kelas menengah Muslim di Indonesia sendiri merupakan pembahasan kebangkitan masyarakat dalam beradaptasi di iklim modernisme seraya memegang prinsip-prinsip ortodoks agama. Kelas menengah Muslim di

${ }^{27}$ Rofhani, "Budaya Urban Muslim Kelas Menengah", Teosofi, Vol. 3, No. 1 (2013), 181-210. 
Indonesia merupakan perwujudan sebuah masyarakat yang ingin menjadi pemain utama dalam sebuah negara dengan memegang kendali akar-akar kelasnya. Hal inilah yang menjadikan kelas menengah Muslim kemudian berperan penting dalam agen perubahan di Indonesia hingga kini.

\section{Daftar Rujukan}

Ahmad, Kamaruzzaman. "Melacak Akar Sosial-Politik Intelektual Islam Indonesia: Sebuah Survey Bibliografis", Kyoto Review of Southeast Asia, Vol. 8-9, 2007.

Alatas, Syed Farid. "Ideology and Utopia in The Discourse on Civil Society" dalam Johan Saravanamuttu, Islam and Politic in Southeast Asia. New York: Routledge, 2010.

Arifin, Syahrial. "Islam dan Pembebasan", dalam http://indoprogress.com/2012/08/Islam-dan-pembebasan /Dia kses 28-03-2015.

Baso, Ahmad. Civil Society versus Masyarakat Madani: Arkeologi Pemikiran Civil Society dalam Islam Indonesia. Jakarta: Pustaka Hidayah, 1999.

Dhofier, Zamakhsyari. Tradisi Pesantren: Studi tentang Pandangan Hidup Kyai. Jakarta: LP3ES, 1994.

Dick, Howard. "The Rise of A Middle Class and Changing Concept of Equity in Indonesia", Indonesia, Vol. 39, No. 1, 1985.

Fathurahman, Oman. "Jaringan Ulama: Pembaharuan dan Rekonsiliasi dalam Tradisi Intelektual Islam di Dunia MelayuIndonesia", Studia Islamika, Vol. 11, No. 2, 2004.

Feith, Herber., dan Castle (eds.). Pemikiran Politik Indonesia 1945-1965. Jakarta: LP3ES, 1988.

Geertz, Clifford. Peddlers and Princes: Social Development and Economic Change in Two Indonesian Towns. Chicago: University Of Chicago Press, 1963.

Hasbullah, Moeflich. "Kompleksitas dan Jaringan Rumit Ulama Nusantara”, dalam www.academia.edu/ 9550136/Book_ Review_Jaringan_Ulama_Azra. Diakses 17-03-2015.

Hefner, Robert. "Islam, State, and Civil Society: ICMI and the Struggle for the Indonesian Middle Class", Indonesia, Vol. 56, No. 3, 1993.

Heryanto, Ariel. Upgraded Piety and Pleasure: The New Middle Class and Islam in Indonesian Popular Culture in Andrew Weintraub, Islam and Popular Culture in Indonesia and Malaysia. New York: Routledge, 2008. 
Howell, Julia. "Modulations of Active Piety: Professors and Televangelists as Promoters of Indonsian Muslim Sufism" dalam Fealy, Greg. Expressing Islam: Religious Life and Politics in Indonesia. Singapore: Routledge, 2008.

Jati, Wasisto R. "Agama dan Politik: Teologi Pembebasan sebagai Arena Profetisasi Agama”, Walisongo, Vol. 22, No. 1, 2014.

Kitley, Philip. "Civil Society and The Media In Indonesia" dalam Azyumardi Azra, Islam Beyond Conflict. Hampshire: Ashgate, 2008.

Kuntowijoyo. Paradigma Islam: Interpretasi untuk. Aksi. Bandung: Mizan Press, 2008.

Latief, Hilman. Melayani Umat: Filantropi Islam dan Ideologi Kesejabteraan Kaum Modernis. Jakarta: Gramedia Pustaka Utama, 2010.

Mas'udi, Wawan. "Masyarakat Madani: Visi Etis Islam tentang Civil Society", Jurnal Ilmu Sosial dan Ilmu Politik, Vol. 3, No. 2, 1999.

Nakamura, Mitsuo. The Crescent Arises over the Banyan Tree: A Study of the Muhammadiyah Movement in a Central Javanese Town: 1910-2010. Singapore: ISEAS Press, 2012.

Qodir, Zuly. Muhammadiyah Studies: Reorientasi Gerakan dan Pemikiran Memasuki Abad Kedua. Yogyakarta: Kanisius, 2010.

Rofhani. "Budaya Urban Muslim Kelas Menengah", Teosofi, Vol. 3, No. 1, 2013.

Shiraishi, Takashi. Zaman Bergerak: Radikalisme Rakyat di Jawa 1912 1926. Jakarta: Grafiti Press, 1997.

Taher, Tarmizi. Agama Kemanusiaan, Agama Masa Depan: Kontekstualisasi Kritis Doktrin Agama dalam Pembangunan dan Percaturan Global. Jakarta: Grafindo, 2004.

Weber, Max. Etika Protestan dan Spirit Kapitalisme. Yogyakarta: Pustaka Pelajar, 2006.

Wetheim, WF. Masyarakat Indonesia dalam Transisi: Kajian Perubahan Sosial. Yogyakarta: Tiara Wacana, 2010. 